\title{
Optimization of Protein Recovery from Bovine Lung by pH Shift Process Using Response Surface Methodology
}

\author{
Authors \\ Sarah A. Lynch ${ }^{1,2}$, Carlos Alvarez ${ }^{1}$, Eileen O’Neill ${ }^{2}$ Derek F. Keenan ${ }^{1}$, Anne \\ Maria Mullen ${ }^{1}$
}

\section{Author affiliations}

1 Food Quality and Sensory Science, Teagasc Food Research Centre,

Ashtown, Dublin 15, Ireland

2 Department of Food and Nutritional Sciences, University College Cork, Cork, Ireland

\section{Corresponding author contact details}

Anne.mullen@teagasc.ie

\begin{abstract}
:
Background: Response surface methodology (RSM) was used in a sequential manner to optimize solubilization and precipitation conditions in the recovery of protein from bovine lung using $\mathrm{pH}$ shift.
\end{abstract}

This article has been accepted for publication and undergone full peer review but has not been through the copyediting, typesetting, pagination and proofreading process, which may lead to differences between this version and the Version of Record. Please cite this article as doi: $10.1002 /$ jsfa.8678 
Result: Separate D-optimal designs were employed for protein solubilization and precipitation. Independent variables investigated for protein solubilization were time (10-120 minutes), temperature $\left(4-20^{\circ} \mathrm{C}\right), \mathrm{pH}(8-11)$ and solvent sample ratio (2.5-10). Variables for protein precipitation were time (0-60 minutes) and $\mathrm{pH}$ (4.25-6.00). Soluble protein yield ranged from $329 \mathrm{~g} \mathrm{~kg}^{-1}$ to $647 \mathrm{~g} \mathrm{~kg}^{-1}$ and the quadratic model for protein solubilisation revealed a coefficient of determination $R^{2}$ of 0.9958 . Optimum conditions for maximum protein solubility were extraction time of 140 minutes, temperature $19^{\circ} \mathrm{C}, \mathrm{pH} 10.8$ and solvent sample ratio 13.02 . Protein precipitation yields varied from $407 \mathrm{~g} \mathrm{~kg}^{-1}$ to $667 \mathrm{~g} \mathrm{~kg}^{-1}$ giving a coefficient of determination $R^{2}$ of 0.9335 . The optimum conditions for maximum protein precipitation were $\mathrm{pH} 5.03$ and 60 minutes. Based on the RSM model, solubilization conditions were manipulated to maximize protein solubilization under reduced water and alkaline usage. These conditions were also validated.

Conclusion Models for solubilization and precipitation using bovine and porcine lung were validated; predicted and actual yields were in good agreement showing cross species applicability of the results.

Keywords: Protein solubilization, protein precipitation, pH shift, bovine offal, response surface methodology.

\subsection{Introduction}

In recent decades the consumption of offal has decreased in Western Europe due to changing eating habits and health concerns. ${ }^{1}$ Although these products are suitable for human consumption, in many cases due to difficulties in accessing suitable markets they are rendered or used in the production of pet food. ${ }^{2} \mathrm{~A}$ 
potential approach to increase the value of these co-products is to extract their proteins for use as functional ingredient in meat products. ${ }^{1}$

Research into the recovery of protein from low value meats and co products has used a variety of methods including enzyme hydrolysis ${ }^{3}$ salt extraction ${ }^{4}$, anionic detergent solubilisation ${ }^{5}$ surimi processing s,7 $^{6,7}$ acid or alkaline extractions. ${ }^{1,8,9}$ Earlier research tended to be more concerned with the fabrication of meat analogue products that were suitable for use as a meat extender. ${ }^{10-12}$ The solubilisation methods used in these studies may be applied to the recovery of functional proteins from offal such as lung. When choosing a method for the recovery of proteins it should be effective in recovering the maximum yield of protein without causing significant reduction in protein functionality due to denaturation. ${ }^{10}$

Acid or alkaline solubilization followed by isoelectric precipitation is a non-thermal process that has been successfully used to recover proteins from various muscle sources such as heart, ${ }^{8}$ trout, ${ }^{13}$ tilapia, ${ }^{14}$ herring, ${ }^{15}$ chicken ${ }^{16}$ and lung ${ }^{17}$. This process may be more suitable than the surimi process to recover proteins from co products, by solubilizing myofibrillar protein in dilute acid or alkaline conditions as higher protein yields have been reported using this process compared surimi processing. ${ }^{18}$ Protein extraction yields from sources including meat co-products are influenced by process conditions such as extraction time, temperature, ${ }^{19}$ ionic strength ${ }^{5}$ and ratio of extraction solvent to sample ${ }^{20,21}$ and also the nature of the starting material.

Lung is of particular interest, as it is a relatively large organ which currently commands low value and tends to be used mostly for pet food. Lung has a protein

This article is protected by copyright. All rights reserved. 
content of approximately $170 \mathrm{~g} \mathrm{~kg}^{-1}{ }^{19}$ and while it has high connective tissue content accounting for approximately $150-205 \mathrm{~g} \mathrm{~kg}^{-1}$ of the total protein, ${ }^{22,23} \mathrm{a}$ significant amount of potentially functional protein is still available for recovery.

In previous studies Selmane and co-workers ${ }^{1,17}$ have used alkaline conditions to extract protein from bovine lung and investigated one factor at a time to determine the optimum conditions for extraction. They identified $\mathrm{pH}$ as the critical factor for protein solubilization and demonstrated to a lesser extent, the influence of time and temperature on protein extraction. The effect of solvent sample ratio on protein yield and possible interactions between processing variables were not investigated. Furthermore conditions for protein recovery by precipitation were not optimized. In order to maximize protein recovery, the optimum processing conditions must be identified and the interactions between different processing parameters need to be better understood. Response surface methodology (RSM) can be used to determine relevant processing characteristics such as optimum operating conditions and identify interactions between processing conditions. ${ }^{24}$ RSM has previously been used to optimise the recovery of protein from different sources such as egg shell membrane, ${ }^{25}$ watermelon seeds ${ }^{26}$ and red pepper seeds. ${ }^{27}$

In this study RSM was used in a sequential manner to initially optimise conditions for solubilization of protein from bovine lung tissue, and subsequently to maximize recovery of soluble proteins using a precipitation step. The optimal conditions were validated, tested at larger lab-scale and then validated. Additionally, species effect was studied by validating the RSM model obtained using porcine lungs. Interactions between variables influencing protein solubilization yield were identified and a number of protein solubilization processing conditions which This article is protected by copyright. All rights reserved. 
might be more practical in an industrial context were investigated. Using the RSM models generated extraction conditions were manipulated to predict maximum protein solubilization under process constraints of reduced water and alkaline usage. Conditions were validated using bovine lung and actual yields achieved were compared to those predicted.

\section{Experimental}

\section{Reagents}

All chemicals and reagents used in this study (sodium hydroxide, hydrochloric acid, sulfuric acid, citric acid monohydrate, sodium acetate trihydrate, 1-propanol, chloramine-T, 4-dimethylaminobenzaldehyde, perchloric acid, 2-propanol and hydroxyproline standard) were purchased from Sigma Aldrich (Ireland) and were analytical grade ACS.

\section{Raw materials}

Bovine lung samples were collected from commercial breeds slaughtered at an abattoir and transported to Teagasc Food Research Centre Ashtown on day of slaughter. Porcine lung from commercial breeds were collected at time of slaughter of animals at the abattoir facility at Teagasc Food Research Ashtown. Bovine and porcine samples never were mixed and were stored separately below $3^{\circ} \mathrm{C}$ for 24 hours before mincing using a Mainca Mincer fitted with a $5 \mathrm{~mm}$ plate. A bulk sample for bovine lung was prepared by mixing equal amounts of minced bovine lung from 4 different animals in a Robot Coupe; this covered the full RSM experiment as well as validation and scale up. A separate bulk sample for porcine lung was prepared in the same way, this covered validation and scale up 
experiments. Bulk samples are referred to as being either bovine or porcine lung. Minced samples were frozen at $-20^{\circ} \mathrm{C}$ until use.

\section{Protein extraction}

Bovine lung protein was extracted under 25 different combinations of the independent variables of extraction time $(10-120$ minutes $)$, temperature $\left(4-20^{\circ} \mathrm{C}\right)$, $\mathrm{pH}$ (8-11) and solvent sample ratio (2.5-10) shown in Table 1. A $250 \mathrm{~mL}$ homogenate was prepared from minced lung and distilled water using laboratory blender (Waring) setting 5, fitted with a $1 \mathrm{~L}$ stainless steel container. Tissue and water were first homogenized in a ratio of $1: 1$ for 15 seconds, the remaining water was then added and homogenized for a further 15 seconds. The protein extraction was carried out in water jacked beakers connected to a circulating water bath (Grant LTD6/20) to maintain a constant temperature. The homogenate was allowed to reach the specified temperature before $\mathrm{pH}$ was adjusted using $\mathrm{NaOH} 5 \mathrm{~mol} \mathrm{~L}^{-1}$. The homogenate was stirred using an overhead stirrer for the designated extraction time, with temperature and $\mathrm{pH}$ being maintained throughout. After extraction time was completed, the solubilized protein was separated from insoluble material by centrifugation at $10,000 \mathrm{~g}$ for $20 \mathrm{~min}$ at $4^{\circ} \mathrm{C}$ (Sigma 6K10). The supernatant (S1) was decanted through a double layer of cheese cloth. Small specks of white residue (fat particles) on the top of the supernatant were observed, that were retained on the cheese cloth during. Subsequently protein content in the supernatant (S1) and pellet (P1) were measured using LECO and based on wet weight of samples.

Protein solubilization was calculated as

$[$ (weight $\mathrm{x}$ protein concentration of supernatant 1$) /$ (weight $\mathrm{x}$ protein content of tissue)] $\mathrm{X} 100$ and expressed in $\mathrm{g} \mathrm{kg}^{-1}$

This article is protected by copyright. All rights reserved. 


\section{Protein precipitation}

Precipitation of solubilized proteins from S1 was optimised using RSM approach. A range of $\mathrm{pH}$ values, close to the isoelectric point of meat proteins, were used to precipitate protein from the supernatant (S1). An experimental design with 17 combinations (Table 2) of the independent variables of $\mathrm{pH}(4.25-6.0)$ and time (060 minutes) was used. Blocks were used to account for any variation in the soluble protein prepared on different days for precipitation. During the precipitation process the temperature was maintained below $4{ }^{\circ} \mathrm{C}$ using circulating water bath (Grant LTD6/20). The $\mathrm{pH}$ of the supernatant obtained in protein solubilisation (S1) was adjusted using $\mathrm{HCl}\left(37 \mathrm{~g} \mathrm{~kg}^{-1}\right)$ according to the experimental conditions. The recovered proteins were separated by centrifugation at $10,000 \mathrm{~g}$ for 20 minutes at $4^{\circ} \mathrm{C}$ (Sigma $\left.6 \mathrm{~K} 10\right)$. Protein content in the pellet (P2) was measured using LECO and based on wet weight of samples. The percentage protein precipitated was calculated from the following equation Protein precipitation was calculated as [(Weight $\mathrm{x}$ protein content of pellet 2) / (weight $\mathrm{x}$ protein content of supernatant 1)] $X 100$ and expressed in $\mathrm{g} \mathrm{kg}^{-1}$

\section{Composition analysis}

Proximate analysis

Protein content was determined based on the measurement of nitrogen by combustion using a LECO FP628 (LECO Corp., MI, USA) Protein analyzer based on the Dumas method according to the AOAC method. ${ }^{29} \mathrm{~A}$ factor of 6.25 was used to convert nitrogen to crude protein per cent. Fat and moisture content were This article is protected by copyright. All rights reserved. 
measured using Smart System 5 (Smart Trac 5 Model 907875, CEM Corporation, NC, USA) microwave drying oven and NMR Smart Trac rapid Fat Analyzer (CEM Corporation USA) using AOAC Official Methods for moisture ${ }^{30}$ and, fat. ${ }^{31}$ Ash content was measured using a dry ashing method. ${ }^{32}$

\section{Collagen}

Total collagen in lung tissue and insoluble material was calculated from hydroxyproline content according to the method of Kolar $1990 .^{33}$

\section{Experimental design}

Response surface methodology (RSM) was used to optimise extraction and precipitation of protein from bovine lung. Two separate response surface experiments were designed and analysed using Design Expert ( $v$ 7.6.1, StatEase Inc., Minneapolis, MN, USA). Separate D-optimal designs were employed in a sequential manner first to optimise the solubilisation of protein from bovine lung followed by the recovery of solubilized protein by isoelectric precipitation.

In design model 1 (DM1), optimization of protein solubilization shown in Table 1, the effects of four independent variables, time (10-120 minutes), temperature (4$\left.20^{\circ} \mathrm{C}\right), \mathrm{pH}(8-11)$, and solvent sample ratio $(2.5-10)$ on protein yield were investigated. Upper and lower limits of the independent variables were selected from preliminary tests and published data. ${ }^{1,9,19-21}$ Using a D-optimal design, 25 combinations were generated using the software. Within these combinations, 5 were repeated twice (Run No.1= Run No.17, 8=25, 12=21, 14=23 and 18=22) to assess error within the model. Each of the experimental combinations was 
performed in triplicate and the mean soluble protein yield was used as the response.

In design model 2 (DM2), optimization of protein recovery by precipitation shown in Table 2, the $\mathrm{pH}$ range was selected based on published data. ${ }^{1,17,28}$. The effect of the independent variables, time (0-60 minutes) and $\mathrm{pH}(4.25-6.00)$ on protein precipitation were investigated using a D-Optimal design and a total of 17 experimental conditions were used. Each precipitation was carried out in triplicate and the mean yield of precipitated protein was used as the response. Within the 17 conditions, 4 were repeated twice (Run No.1= Run No.4, 7=8, 12=13 and 6 $=17$ ) to estimate error within the model. Blocking was applied to account for any batch to batch variation of the protein solubilized from bovine lung (S1); 4 blocks were used corresponding to different batches of S1. The supernatant was produced using the conditions established as the optimum for maximum soluble protein yield according to DM1. Analysis of variance was carried out on the response of yield for each of the 2 models DM1 and DM2 to identify the coefficient of determination $\left(\mathrm{R}^{2}\right)$, lack of fit and significant difference.

\section{Optimization of soluble and precipitated protein yields and model} validation

The Design Expert optimization tool was used to calculate the optimal conditions to protein yield for both models. In the case of DM 1 levels of time, temperature, $\mathrm{pH}$ and solvent sample ratio were optimized for maximum soluble protein yield. Due to the robustness of the model generated, the optimization tool allowed for prediction of soluble protein yield using conditions that were slightly outside of the range tested in the original design model. This feature was also used to maximize 
soluble protein yield under certain processing constraints which may be more attractive to industry from a sustainability point. The processing constraints tested included reducing $\mathrm{pH}$ and solvent sample ratio with a view to understanding the impact of reduced sodium hydroxide and water usage in the process. The optimized conditions for maximum soluble protein yield, and maximum yield under processing constraints were validated to assess the validity of the model.

To optimize the precipitation of the solubilized proteins in DM 2 conditions of $\mathrm{pH}$ and time were optimized. The parameters highlighted as best for optimal yield for DM1 and DM2 were also applied to the extraction and recovery of soluble protein from porcine lung in order to assess the applicability of the results on the same material from different species. Following validation of DM1 and DM2 separately, the process was scaled up to $2 \mathrm{~L}$. The optimum conditions to maximize protein yield were used in sequence to solubilize and precipitate protein from bovine and porcine lung.

\section{Statistical analysis}

Data relating to the optimization of protein solubilisation from lung (DM1) and precipitation of protein solubilized from lung (DM2) was analysed using the Design Expert (v 7.6.1, Stat-Ease Inc., Minneapolis, MN, USA) as part of the optimization experiments. Data relating to the composition of starting material and fractions recovered throughout the process were analysed using PASW Statistics 18 (SPSS Chicago, IL, USA). Independent samples t-test was used to compare composition and yield between species. The significance level for all 
tests was established at $\mathrm{P}<0.05$, and homogeneity of variance was checked using Levene's test.

\section{Results and Discussion}

\section{Solubilisation optimization}

The experimental design for protein solubilisation DM1 generated 25 experimental combinations (Table1), with soluble protein yield ranging from 329 $\mathrm{g} \mathrm{kg}^{-1}$ to $647 \mathrm{~g} \mathrm{~kg}^{-1}$. The quadratic model was significant $(P<0.0001)$ and the coefficient of determination $R^{2}$ of 0.9958 was satisfactory. The predicted $R^{2}$ of 0.9251 is in reasonable agreement of the adjusted $R^{2}$ of 0.9898 . The analysis of error indicated that the lack of fit test was not significant $(P=0.3757)$ confirming the validity of the model. The application of RSM yields the following regression equation which is an empirical relationship between soluble protein yield $Y$ and the independent variables.

$$
\begin{aligned}
& Y=50.66+(0.87 * A)+(2.31 * B)+(6.28 * C)+(6.92 * D)+(0.63 * A * B)+ \\
& (0.18 * A * B)+(0.22 * A * D)-(1.06 * B * C)+(0.041 * B * D)-(0.33 * C * \\
& D)-\left(0.54 * A^{2}\right)-\left(0.90 * B^{2}\right)+\left(0.13 * C^{2}\right)-\left(1.52 * D^{2}\right)
\end{aligned}
$$

Where

$$
\begin{aligned}
& A=\text { time in minutes } \\
& B=\text { temperature }{ }^{\circ} \mathrm{C} \\
& C=p H \\
& D=\text { solvent sample ratio }
\end{aligned}
$$

This article is protected by copyright. All rights reserved. 
To illustrate the main and interactive effects of the independent variables on protein solubilisation yield, 3D contour plots for DM1 are shown in Figure 1. The perturbation plot in Figure 2 shows the sensitivity of soluble protein yield to the independent variables. A steep curvature or slope is an indication that the response is sensitive to that variable while a relatively flat line shows that the response is less sensitive to changes in that particular factor. ${ }^{34}$ In the case of DM1 soluble protein yield appears to be more sensitive to solvent sample ratio and $\mathrm{pH}$ than time or temperature.

Results from this study show that $\mathrm{pH}$ had a significant influence on soluble protein yield $(P<0.0001)$. Protein solubilization from lung, rumen and intestine ${ }^{28}$ and fish muscle ${ }^{13,14}$ has been previously seen to increase as $\mathrm{pH}$ moves away from the isoelectric point, and is maximum at high and low $\mathrm{pH}$ values. Analysis of variance also shows temperature to have a significant impact on soluble protein yield $(P<0.0001)$. It has previously been shown that an increase in extraction temperature can lead to increase in the rate of protein solubilization from bovine heart, kidney and lung. ${ }^{19}$ The interaction of $\mathrm{pH}$ and temperature on soluble protein yield was significant $(P=0.0016)$ is shown in Figure 1a. The extraction of protein from animal co products at $20^{\circ} \mathrm{C}, 30^{\circ} \mathrm{C}$ and $40^{\circ} \mathrm{C}$ was investigated was by Selmane et al. ${ }^{1}, 20^{\circ} \mathrm{C}$ was most suitable for lung protein recovery while $40{ }^{\circ} \mathrm{C}$ was more suitable for mechanically deboned chicken meat. In this study to reduce the risk of protein degradation we focused on temperatures $20^{\circ} \mathrm{C}$ and below, and saw that while temperature had a significant effect on soluble protein yield, it displayed less of an influence than $\mathrm{pH}$ or solvent sample ratio. Although $20^{\circ} \mathrm{C}$ was the optimal temperature for maximum soluble protein yield comparison of Run no. 1 and 13 (Table1) showed that at least $600 \mathrm{~g} \mathrm{~kg}^{-1}$ of protein is solubilized

This article is protected by copyright. All rights reserved. 
even when temperature is reduced from 20 to $4{ }^{\circ} \mathrm{C}$ when the more influential factors of $\mathrm{pH}$ and solvent sample ratio were at the upper limits. Similarly Swingler and Lawrie ${ }^{19}$ in a study not concerned with protein functionality reported that although yield increased with extraction temperature, no more than $600 \mathrm{~g} \mathrm{~kg}^{-1}$ of lung protein could be extracted at $60^{\circ} \mathrm{C}$, furthermore extraction at this temperature resulted in the formation of lysinoalaine $(L A L)$. The presence of $L A L$ reduces the nutritional quality of the protein. Comparison of the soluble protein yield for Run no. 1 and 10 (Table1) showed a moderate increase in yield when extraction time increased from 10 to 120 minutes, when the other factors were at the upper limits. Previously it was found that the greatest degree of protein solubilisation from lung and stomach occurred in the first hour of extraction ${ }^{5}$ and extraction times above 2 hours had little benefit on the yield of protein extracted from lung. ${ }^{19}$ The interaction of extraction time and temperature does show a significant effect $(P=0.0257)$ on soluble protein yield as seen in Figure $1 \mathrm{~b}$ where soluble protein yield appears to be more sensitive to temperature.

While solvent sample ratio was a significant factor $(P<0.0001)$ as was its quadratic model term $(P=0.0403)$ it was not involved in any significant interactions. The influence of solvent sample ratio on soluble protein yield may be due to the effect solvent sample ratio has on viscosity. A low viscosity aids the separation of insoluble material from solubilized proteins by centrifugation. ${ }^{35}$ During extraction of muscle proteins using $\mathrm{pH}$ adjustment, homogenization and solubilization are assisted by a higher solvent sample ratio, additionally the loss of soluble proteins in the insoluble sediment is reduced. ${ }^{13}$ An increase in solvent sample ratio from 6:1 to 9:1 resulted in an increase in protein solubilization from 
blue mussel, the result was more pronounced from protein isolated using acidic conditions that alkaline conditions. ${ }^{21}$

\section{Precipitation optimisation}

The experimental design for protein precipitation DM2 generated 17 experimental combinations (Table 2). Precipitated protein yield ranged from $407 \mathrm{~g} \mathrm{~kg}^{-1}$ to 667 $\mathrm{g} \mathrm{kg}^{-1}$. A quadratic model was found to be significant $(P=0.0002)$ the coefficient of determination $\mathrm{R}^{2}$ of 0.9335 was adequate. There is however some indication that a factor not included in the model is influencing precipitated protein yield, as indicated by the adjusted $R^{2}$ of 0.8920 . The analysis of error, lack of fit test was not significant $(P=0.1210)$ indicating that the model was valid. The regression equation for the yield of precipitated protein $Y$ was as follows

$$
\begin{aligned}
& Y=59.58-(2.71 * A)-(0.20 * B)-(0.17 * A * B)-\left(8.88 * A^{2}\right)+\left(2.08 * B^{2}\right) \\
& \text { Where } \\
& \qquad \mathrm{A}=p H \\
& \qquad \mathrm{~B}=\text { time in minutes }
\end{aligned}
$$

Statistical analysis of DM2 shows the effect of time and $\mathrm{pH}$ on the precipitated protein yield. Based on analysis of variance (Table 4), $\mathrm{pH}$ was a significant factor $(\mathrm{P}=0.0014)$ as was the quadratic model term for $\mathrm{pH}(P<0.0001)$. There was no significant interaction between $\mathrm{pH}$ and time $(\mathrm{P}=0.8209)$. The 3D contour plot for DM2 presented in Figure 3 demonstrates that $\mathrm{pH}$ has a greater effect on yield than time; this is also seen in the perturbation plot in Figure 4. Protein yield increases in line with $\mathrm{pH}$ from 4.25 up to approximately $\mathrm{pH} 5.1$ and then protein 
yield declines as $\mathrm{pH}$ increases. While the maximum precipitated protein yield of $667 \mathrm{~g} \mathrm{~kg}^{-1}$ for precipitation optimization (DM2) may be moderate, it appears to be in agreement with other research concerned with the recovery of soluble protein by precipitation. Gault and Lawrie ${ }^{28}$ found that extraction at $\mathrm{pH} 10.5$ solubilized $550 \mathrm{~g} \mathrm{~kg}^{-1}$ of total lung tissue nitrogen, however following precipitation at $\mathrm{pH} 4.5,260 \mathrm{~g} \mathrm{~kg}^{-1}$ of total tissue nitrogen remained in solution. When they analysed the unrecovered protein by electrophoresis, a major protein band with a molecular weight close to $70 \mathrm{kDa}$ remained in solution, the authors suggested that this protein may be an albumin type protein from the cytoplasm of smooth muscle cells.

Based on the maximum precipitated protein yield achieved, it is evident that $\mathrm{pH}$ adjustment alone is not sufficient for the efficient recovery of solubilized protein. It is possible that residual $\mathrm{NaCl}$ due to $\mathrm{pH}$ adjustments may have altered the ionic strength of the solution affecting the solubility and precipitation of the proteins. Young and Lawrie ${ }^{5}$ reported the solubility of proteins from lung and stomach at high and low $\mathrm{pH}$ is reduced as salt concentrations increase while conversely protein solubility in the $\mathrm{pH}$ range 4-6 increases with salt concentration. Similarly Dewitt and James ${ }^{8}$ reported that in the presence of $0.05 \mathrm{~mol} \mathrm{~L}^{-1} \mathrm{NaCl}$, solubility of protein from beef heart increased at the isoelectric point. SDS PAGE of the protein still in solution after precipitation showed a major protein band close to 66 $\mathrm{kDa}$. It is worth noting that not all proteins are insoluble at their isoelectric point, one example is blood albumin, the isoelectric point of this protein is $\mathrm{pH} 4.9^{36}$, but has solubility above $600 \mathrm{~g} \mathrm{~kg}^{-1}$ at $\mathrm{pH} 4-5 .{ }^{37,38}$

\section{Optimization of conditions and validation of models}

This article is protected by copyright. All rights reserved. 
Validation of the model must be carried out to ensure the quality and reliability of results for prediction of soluble protein yield and precipitated protein yield. Validation of model optimization for protein solubilization and protein precipitation were carried out at bench scale with the volumes employed in generating the models, $250 \mathrm{~mL}$ for extraction and $100 \mathrm{~mL}$ for precipitation. According to DM1, the optimum conditions for maximum solubilization of protein from bovine lung are 140 minutes, $19{ }^{\circ} \mathrm{C} \mathrm{pH} 10.8$ and sample solvent ratio of 13.02 and a desirability value of 1.000 , (MV1) shown in Table 5 . These conditions were established by the optimisation tool of the Design Expert software to maximize soluble protein yield. Under these optimum conditions a soluble protein the yield of $665 \mathrm{~g} \mathrm{~kg}^{-1}$ was predicted, the actual experimental yield achieved of $661 \mathrm{~g} \mathrm{~kg}^{-1}$ is in good agreement indicating that the model is valid.

The optimization tool was also applied to the optimization of soluble protein yield, under certain processing constraints that may be relevant to industrial scale up of the process, namely the reduction of $\mathrm{NaOH}$ and water used in the process (Table 5). This was achieved by setting the maximum independent variable to levels that were a compromise between soluble protein yield and reduced water and $\mathrm{NaOH}$ usage. To reduce the amount of $\mathrm{NaOH}$ used a maximum $\mathrm{pH}$ value was set to 8.4 , this more moderate $\mathrm{pH}$ may also be beneficial in maintaining the functionality of the protein by preventing the denaturation during the solubilization step. In order to reduce the amount of water used in the process solvent sample ratio was set to a maximum level of 7.5 , although a reduction in water used in the process has an obvious benefit to the industry namely that the resulting supernatant has a higher protein content, the trade-off is a reduction in soluble protein yield. The solvent sample ratio of 7.5 represented a compromise between

This article is protected by copyright. All rights reserved. 
soluble protein yield and a supernatant that would require less energy to concentrate before drying. The differences in the predicted and actual yields achieved for MV-1 and MV-5 of Table 5 demonstrate the impact on yield of reducing solvent sample ratio from 13.02 to 7.5 . While maximum soluble protein yield is achieved with the higher solvent sample ratio, due to high water demand it may be more practical to use a reduced solvent sample ratio of 7.5 that can still achieve a soluble protein yield of at least $600 \mathrm{~g} \mathrm{~kg}^{-1}$; which is a desirability value of 0.902 . Comparisons between the predicted and actual yields of soluble protein extracted under processing constraints further confirm the accuracy of the model.

The model for DM1 was established using bovine lung; it was also of interest to see how accurate the model would perform using material from another species. To this end optimized conditions for protein solubilization were also applied to porcine lung. Comparison of soluble protein yield between bovine and porcine lung using the conditions for MV1 $(P=0.184)$ and MV2 $(P=0.773)$ showed no significant difference in soluble protein yield, between species under the same conditions.

Once the optimum conditions for protein solubilization had been established (Table 5), with the conditions for maximum protein solubilization achieved using MV-1, the next step was to optimise protein precipitation yield using DM2 (Table2). Based on the results of DM2 the optimization tool of the software was used to predict the optimum conditions to achieve a maximum yield of precipitated protein. The conditions identified as the optimum are $\mathrm{pH} 5.03$, precipitation time 60.0 minutes to give a predicted protein yield of $617 \mathrm{~g} \mathrm{~kg}^{-1}$ and a desirability level of 0.81 . The experimental yield achieved for bovine lung was This article is protected by copyright. All rights reserved. 
$545 \mathrm{~g} \mathrm{~kg}^{-1}$, and porcine lung was $533 \mathrm{~g} \mathrm{~kg}^{-1}$, again there was no significant difference in the yield between species $(P=0.695)$. The experimental yields although lower than predicted are still in close agreement. It is noted that this predicted maximum yield $\left(617 \mathrm{~g} \mathrm{~kg}^{-1}\right)$ differs from the maximum yield seen in Run 9 of DM2 (667 $\left.\mathrm{g} \mathrm{kg}^{-1}\right)$ achieved at $\mathrm{pH} 5.13$ and 60 minutes. This Run was identified as having a yield higher than the predicted yield for these precipitation conditions.

In order to test the robustness of the models, the process was scaled up and an extraction volume of $2 \mathrm{~L}$ was used. The suitability of the models in predicting yield of soluble protein and precipitated protein is further confirmed by the actual yields achieved with increased extraction volume as seen in Table 6. Optimum conditions for protein solubilization and precipitation were also applied to porcine lung. No significant difference between species was found for soluble protein yield $(P=0.119)$ or precipitated protein yield $(P=0.342)$. Comparison of yield of soluble protein at a volume of $250 \mathrm{~mL}$ compared to $2 \mathrm{~L}$ shows no significant difference for bovine $(P=0.968)$ or porcine $(P=0.185)$ lung.

There was also no significant difference in the yield of precipitated protein from porcine lung $(P=0.290)$, however in the case of bovine lung, there was a significant increase $(P=0.018)$ in protein precipitation yield when volume was increased to $2 \mathrm{~L}$.

It is apparent from the yields shown in Table 6 that the second stage, precipitation of soluble protein, is the least efficient step in the $\mathrm{pH}$ shift process. Similar results were seen at this stage of the recovery process from shellfish ${ }^{21}$ and meat coproducts. ${ }^{17,28}$ The overall recovery yield of protein was $440 \mathrm{~g} \mathrm{~kg}^{-1}$ from bovine 
and porcine lung. The increased soluble protein yield seen with porcine lung compared to bovine lung was not seen in the overall yield, due to the inefficiencies in the precipitation step.

\subsection{Composition analysis}

The average compositions of bovine and porcine lung, and protein recovered using the optimum conditions as given by the optimization tool for solubilisation (extraction time 140 minutes, temperature $19^{\circ} \mathrm{C}, \mathrm{pH} 10.8$ and solvent sample ratio (13.02) and precipitation (60 minutes $\mathrm{pH}$ 5.03) are listed in Table 7. Porcine lung had significantly lower protein $(P<0.001)$ and collagen $(P<0.001)$ than bovine lung, and a significantly higher fat $(P<0.001)$ and moisture $(P=0.047)$ content. Similar differences between species were seen by other researchers. ${ }^{1,28}$ Comparison of the composition of recovered protein pellet between species showed moisture to be the only significant difference $(P=0.041)$. No collagen was detected in the recovered protein from either species. The discarded pellet obtained after alkaline solubilisation step (P1) comprised of $67 \mathrm{~g} \mathrm{~kg}^{-1}$ protein and $38 \mathrm{~g} \mathrm{~kg}^{-1}$ collagen for bovine lung and $57 \mathrm{~g} \mathrm{~kg}^{-1}$ protein and $32 \mathrm{~g} \mathrm{~kg}^{-1}$ collagen for porcine lung, with no significant difference between species.

\subsection{Conclusion}

Response surface methodology was successfully used to determine the optimum conditions for the solubilization of protein from bovine lung and the recovery of soluble protein by isoelectric precipitation. For first time interactions between the variables influencing protein solubilization yield were identified and this information was used to maximize protein solubilisation under industrially relevant processing constraints of reduced water or $\mathrm{NaOH}$ usage. The models 
for solubilization and precipitation of protein for bovine lung were successfully validated, and optimum conditions were also applied to porcine lung. Conditions for maximum protein solubilization were $\mathrm{pH} 10.8$, solvent sample ratio of 13.0 , extraction time of 140 minutes and $19^{\circ} \mathrm{C}$, while maximum protein precipitation was achieved by adjusting the $\mathrm{pH}$ of the soluble protein to $\mathrm{pH} 5.03$ and incubation for 60 minutes. Scale up of the process showed the models to be robust. The model for protein precipitation suggested that all variables influencing yield are not accounted for in the model, however the results of the validation and scale up show that the model is a reliable predictor of precipitated protein yield.

\section{Acknowledgements}

Sarah A. Lynch is in receipt of a Teagasc Walsh Fellowship. This work forms part of the ReValueProtein Research Project (Grant Award No. 11/F/043) supported by the Department of Agriculture, Food and the Marine (DAFM) under the National Development Plan 2007-2013 funded by the Irish Government. The authors wish to acknowledge the technical assistance of Ms. Karen Hussey and Ms. Sephora Baugreet.

This article is protected by copyright. All rights reserved. 


\section{References}

1. Selmane D, Christophe V, Gholamreza D, Extraction of proteins from slaughterhouse by-products: Influence of operating conditions on functional properties. Meat Sci 79 (4):640-7 (2008)

2. Fallows SJ, Wheelock JV. By-products from the U.K. food system 2 The meat industry, Conserv Recycl 5(4):173-82 (1982).

3. Webster JD, Ledward DA, Lawrie RA, Protein hydrolysates from meat industry by-products. Meat Sci 7(2):147-57 (1982)

4. Krasnowska G, Gorska I, Gergont J. Evaluation of functional properties of offal proteins. Nahrung 39(2):149-55 (1995).

5. Young $\mathrm{RH}$, Lawrie RA. Utilization of edible protein from meat industry by-products and waste 1 . Factors influencing the extractability of protein from bovine and ovine stomach and lungs. Int J Food Sci Technol 9(1):69-78 (1974).

6. Desmond EM, Kenny TA, Preparation of surimi-like extract from beef hearts and its utilisation in frankfurters. Meat Sci 50(1):81-9. (1998).

7. Nowsad AAKM, Kanoh S, Niwa E, Thermal gelation characteristics of breast and thigh muscles of spent hen and broiler and their surimi. Meat Sci 54(2):169-75 (2000).

8. Dewitt CAM, Gomez G, James JM, Protein Extraction from Beef Heart using Acid Solubilization. J Food Sci 67(9):3335-41. (2002).

9. Jelen P, Earle M, Edwardson W, Recovery of Meat Protein From Alkaline Extracts of Beef Bones. J Food Sci 44(2):327-31 (1979).

10. Young $\mathrm{RH}$, Lawrie RA, Utilization of edible protein from meat industry byproducts and waste. Int J Food Sci Technol 9(2):171-7. (1974).

11. Young $\mathrm{RH}$, Lawrie RA, Utilization of edible protein from meat industry byproducts and waste. Int J Food Sci Technol 10(5):523-32. (1975).

12. Swingler GR, Lawrie RA,Mixed protein fibres from meat industry by-products. Meat Sci 2(2):105-17. (1978).

13. Chen YC, Jaczynski J, Protein recovery from rainbow trout (Oncorhynchus mykiss) processing byproducts via isoelectric solubilization/precipitation and its gelation properties as affected by functional additives. J Agric Food Chem 55(22):9079-88. (2007).

14. Kristinsson HG, Ingadottir B, Recovery and Properties of Muscle Proteins Extracted from Tilapia (Oreochromis niloticus ) Light Muscle by $\mathrm{pH}$ Shift Processing. J Food Sci 71(3):132-41 (2006 ).

This article is protected by copyright. All rights reserved. 
15. Marmon SK, Undeland I, Protein isolation from gutted herring (Clupea harengus) using pH-shift processes. J Agric Food Chem 58 (19):10480-6. (2010).

16. Omana D a., Xu Y, Moayedi V, Betti M, Alkali-aided protein extraction from chicken dark meat: Chemical and functional properties of recovered proteins.

Process Biochem 45(3):375-81. (2010).

17. Darine S, Christophe V, Gholamreza D, Production and functional properties of beef lung protein concentrates. Meat Sci 84:315-22. (2010).

18. James JM, Dewitt CAM, Gel Attributes of Beef Heart When Treated by Acid Solubilisation Isoelectric Precipitation. J Food Sci 69(6):473-80. (2004).

19. Swingler GR, Lawrie RA, Improved protein recovery from some meat industry by-products. Meat Sci 3(1):63-73. (1979).

20. Hamilton RG. Recovery of functional meat proteins from abattoir by-products. CSIRO Food Res Q 38:6-12. (1978).

21. Vareltzis PK, Undeland I, Protein isolation from blue mussels (Mytilus edulis) using an acid and alkaline solubilisation technique-process characteristics and functionality of the isolates. J Sci Food Agric 92(15):3055-64. (2012).

22. Lawrie RA, Ledward DA, Edible Protein Recovery and Upgrading of Meat Packinghouse Waste, in Edible Meat By-Products Advances in Meat Research Volume 5,ed. by Pearson AM, Dutson TR, Elsevier Applied Science Publishers, London, pp. 231-60. (1988).

23. Mullen AM, Álvarez C, Pojić M, Hadnadev TD, Papageorgiou M. Food Waste Recovery. In Food Waste Recovery, ed. by Galanakis CM, Elsevier, Amsterdam, pp. 25-57 (2015).

24. Mason RL, Gunst RF, Hess JL, Designs and Analyses for Fitting Response Surfaces. In: Statistical Design and Analysis of Experiemnets : With Applications to Engineering and Science.: John Wiley \& Sons, New Jersey pp. 568-613 (2003).

25. Mohammadi R, Mohammadifar MA, Mortazavian AM, Rouhi M, Ghasemi JB, Delshadian Z, Extraction optimization of pepsin-soluble collagen from eggshell membrane by response surface methodology (RSM). Food Chem 190: 186-93 (2016).

26 Wani AA, Kaur D, Ahmed I, Sogi DS, Extraction optimization of watermelon seed protein using response surface methodology. LWT - Food Sci Technol 41(8):151420 (2008).

27. Firatligil-Durmus E, Evranuz O, Response surface methodology for protein extraction optimization of red pepper seed (Capsicum frutescens). LWT - Food Sci Technol 43 (2):226-31. (2010).

This article is protected by copyright. All rights reserved. 
28. Gault NF, Lawrie RA, Efficiency of protein extraction and recovery from meat industry by-products. Meat Sci 4(3):167-90 (1980).

29. AOAC, Crude protein in Meat and Meat Products Including Pet Foods992.15, Combustion method, in Official Methods of Analysis of AOAC International ed. by Cunniff P. AOAC International, Arlington, VA: (1996) .

30. AOAC, Moisture in Meat and Poultry Products - Rapid Microwave Drying Method 985.14, in Official Methods of Analysis of AOAC International ed. by Cunniff P. AOAC International, Arlington, VA: (1995).

31. AOAC, Fat (Crude) in meat and poultry products 985.15 , in Official Methods of Analysis of AOAC International ed. by Cunniff P. AOAC International, Arlington, VA: (1995).

32. Kirk RS, Sawyer R, Egan H, in Pearson's Composition of Analysis of Foods. 9th ed. London: Longman, pp. 13-14 (1991).

33. Kolar K. Colormetric Determination of Hydroxyproline as Measure of Collagen Content in Meat and Meat Products: NMKL Collaborative Study. Assoc Off Anal Chem 73:54-7. (1990)

34. Thirumalaikumarasamy D, Shanmugam K, Balasubramanian V. Influences of atmospheric plasma spraying parameters on the porosity level of alumina coating on AZ31B magnesium alloy using response surface methodolog. Prog Nat Sci Mater Int 22(5):468-79. (2012)

35. Bergros Ingadottir. The Use of Acid and Alkali-Aided Protein Solubilization and Precipitation Methods to Produce Functional Protein Ingredients From Tilapia. Thesis. University of Florida Available from: http://ufdc.ufl.edu/UFE0008227/00001 (2004)

36. Putnam FW. Alpha, Beta, Gamma, Omega-The Structure of the Plasma Proteins, In The Plasma Proteins - Structure, Function, and Genetic Control. NewYork: Academic Press. pp. 1-45. (1984).

37. Ramos Clamont G, Fernandez Michel S, Carrillo Vargas L, Martinez Calderon E, Vazquez Moreno L. Functional properties of protein fractions isolated from porcine blood. J Food Sci. 68 (4):1196-200. (2003)

38. Alvarez C, Bances M, Rendueles M, Diaz M. Functional properties of isolated porcine blood proteins. Int J Food Sci Technol 44 (4):807-14. (2009).

This article is protected by copyright. All rights reserved. 


\section{Tables}

Table 1 Experimental design for the optimization of protein solubilisation from bovine lung and the response of mean soluble protein yield (DM1).

\begin{tabular}{|c|c|c|c|c|c|c|c|c|c|}
\hline \multirow[b]{2}{*}{ Run No. } & \multicolumn{4}{|c|}{$\begin{array}{c}\text { Coded } \\
\text { variables }\end{array}$} & \multicolumn{4}{|c|}{ Actual variables } & \multirow{2}{*}{$\begin{array}{c}\text { Soluble protein } \\
\text { yield }\left(\mathrm{g}\left(\mathrm{g} \mathrm{kg}^{-1}\right)\right. \\
\text { Mean } \\
\text { (St. dev.) }\end{array}$} \\
\hline & A & B & C & D & $\begin{array}{l}\text { Time } \\
\text { (Min) }\end{array}$ & Temp ( $\left.{ }^{\circ} \mathrm{C}\right)$ & $\mathrm{pH}$ & $\begin{array}{c}\text { Solvent } \\
\text { Sample } \\
\text { Ratio }\end{array}$ & \\
\hline 1 & 1 & 1 & 1 & 1 & 120 & 20 & 11 & $10: 1$ & $649 \quad(32)$ \\
\hline 2 & 0 & $\begin{array}{l}- \\
1\end{array}$ & $\begin{array}{l}- \\
1\end{array}$ & $\begin{array}{l}- \\
1\end{array}$ & 65 & 4 & 8 & $2.5: 1$ & 323 (23) \\
\hline 3 & -1 & 0 & 0 & 0 & 10 & 12 & 9.5 & $6.25: 1$ & 501 \\
\hline 4 & 0 & 1 & 0 & 0 & 65 & 4 & 9.5 & $6.25: 1$ & 464 (19) \\
\hline 5 & -1 & $\begin{array}{l}- \\
1\end{array}$ & $\begin{array}{l}- \\
1\end{array}$ & 1 & 10 & 4 & 8 & $10: 1$ & 451 (13) \\
\hline 6 & 0 & 0 & 1 & 0 & 65 & 12 & 11 & $6.25: 1$ & 570 (22) \\
\hline 7 & 0.5 & 0 & 0 & 0 & 92.5 & 12 & 9.5 & $6.25: 1$ & $510(40)$ \\
\hline 8 & 1 & $\begin{array}{l}- \\
1\end{array}$ & $\begin{array}{l}- \\
1\end{array}$ & 1 & 120 & 4 & 8 & $10: 1$ & 455 (18) \\
\hline 9 & 0 & 1 & 1 & 1 & 65 & 20 & 11 & $2.5: 1$ & $493(30)$ \\
\hline 10 & -1 & 1 & 1 & 1 & 10 & 20 & 11 & $10: 1$ & $597(14)$ \\
\hline 11 & 0 & 0 & 1 & 0 & 65 & 12 & 8 & $6.25: 1$ & $446(25)$ \\
\hline 12 & 1 & 1 & $\begin{array}{l}- \\
1\end{array}$ & $\begin{array}{l}- \\
1\end{array}$ & 120 & 20 & 8 & $2.5: 1$ & 389 (13) \\
\hline 13 & 0 & 1 & 1 & 1 & 65 & 4 & 11 & $10: 1$ & 603 (19) \\
\hline 14 & -1 & $\begin{array}{l}- \\
1\end{array}$ & 1 & $\begin{array}{l}- \\
1\end{array}$ & 10 & 4 & 11 & $2.5: 1$ & $463(6)$ \\
\hline 15 & 0 & 1 & 0 & 0 & 65 & 20 & 9.5 & $6.25: 1$ & 520 (39) \\
\hline
\end{tabular}

This article is protected by copyright. All rights reserved. 


\begin{tabular}{|c|c|c|c|c|c|c|c|c|c|}
\hline 16 & 0 & 1 & 1 & 1 & 65 & 20 & 8 & $10: 1$ & 527 (30) \\
\hline 17 & 1 & 1 & 1 & 1 & 120 & 20 & 11 & $10: 1$ & 630 (13) \\
\hline 18 & 1 & 1 & 1 & $\begin{array}{l}- \\
1\end{array}$ & 120 & 4 & 11 & $2.5: 1$ & $472(14)$ \\
\hline 19 & -1 & 1 & 1 & 0 & 10 & 20 & 8 & $6.25: 1$ & 454 (32) \\
\hline 20 & -1 & 1 & 0 & 1 & 10 & 20 & 9.5 & $2.5: 1$ & $420(14)$ \\
\hline 21 & 1 & 1 & $\begin{array}{l}- \\
1\end{array}$ & 1 & 120 & 20 & 8 & $2.5: 1$ & 385 (14) \\
\hline 22 & 1 & 1 & 1 & 1 & 120 & 4 & 11 & $2.5: 1$ & 458 (34) \\
\hline 23 & -1 & $\begin{array}{l}- \\
1\end{array}$ & 1 & $\begin{array}{l}- \\
1\end{array}$ & 10 & 4 & 11 & $2.5: 1$ & 459 (13) \\
\hline 24 & -1 & 0 & 1 & 1 & 10 & 12 & 8 & $2.5: 1$ & 338 (21) \\
\hline 25 & 1 & 1 & 1 & 1 & 120 & 4 & 8 & $10: 1$ & 459 (31) \\
\hline
\end{tabular}

Coded variables value $1=$ upper limit, value $-1=$ lower limit $\quad$ A (time); B (temperature); C (pH); (D) Solvent sample ratio

This article is protected by copyright. All rights reserved. 
Table 2 Experimental design for the optimization of protein precipitation from S1, and response of mean precipitated protein yield (DM2).

\begin{tabular}{|c|c|c|c|c|c|c|c|c|}
\hline \multirow{3}{*}{$\begin{array}{c}\text { Run No. } \\
1\end{array}$} & \multicolumn{3}{|c|}{ Coded variables } & \multicolumn{3}{|c|}{ Actual variables } & \multirow{2}{*}{\multicolumn{2}{|c|}{$\begin{array}{l}\text { Precipitated protein } \\
\text { yield }\left(\mathbf{g ~ k g}^{-1}\right) \\
\text { Mean (St. dev.) }\end{array}$}} \\
\hline & Block & A & B & Block & pH & $\begin{array}{l}\text { Time } \\
\text { (Min) }\end{array}$ & & \\
\hline & $\left\{\begin{array}{lll}1 & 0 & 0\end{array}\right\}$ & -1 & 1 & 1 & 4.25 & 60 & 473 & (26) \\
\hline 2 & $\left\{\begin{array}{lll}1 & 0 & 0\end{array}\right\}$ & -1 & -1 & 1 & 4.25 & 0 & 502 & (34) \\
\hline 3 & $\left\{\begin{array}{lll}1 & 0 & 0\end{array}\right\}$ & 0 & 0 & 1 & 5.13 & 30 & 537 & (26) \\
\hline 4 & $\left\{\begin{array}{lll}1 & 0 & 0\end{array}\right\}$ & -1 & 1 & 1 & 4.25 & 60 & 501 & (41) \\
\hline 5 & $\left\{\begin{array}{lll}1 & 0 & 0\end{array}\right\}$ & 1 & 0 & 1 & 6.00 & 30 & 407 & (52) \\
\hline 6 & $\left\{\begin{array}{lll}0 & 1 & 0\end{array}\right\}$ & $\begin{array}{c}- \\
0.5\end{array}$ & 0 & 2 & 4.69 & 30 & 609 & (30) \\
\hline 7 & $\left\{\begin{array}{lll}0 & 1 & 0\end{array}\right\}$ & 1 & -1 & 2 & 6.00 & 0 & 541 & (19) \\
\hline 8 & $\left\{\begin{array}{lll}0 & 1 & 0\end{array}\right\}$ & 1 & -1 & 2 & 6.00 & 0 & 549 & (19) \\
\hline 9 & $\left\{\begin{array}{lll}0 & 1 & 0\end{array}\right\}$ & 0 & 1 & 2 & 5.13 & 60 & 667 & (13) \\
\hline 10 & $\left\{\begin{array}{lll}0 & 0 & 1\end{array}\right\}$ & 0.5 & $\begin{array}{c}- \\
0.5\end{array}$ & 3 & 5.56 & 15 & 563 & (46) \\
\hline 11 & $\left\{\begin{array}{lll}0 & 0 & 1\end{array}\right\}$ & $\begin{array}{c}- \\
0.5\end{array}$ & 0.5 & 3 & 4.69 & 15 & 557 & (16) \\
\hline 12 & $\left\{\begin{array}{lll}0 & 0 & 1\end{array}\right\}$ & 1 & 1 & 3 & 6.00 & 60 & 472 & (24) \\
\hline 13 & $\left\{\begin{array}{lll}0 & 0 & 1\end{array}\right\}$ & 1 & 1 & 3 & 6.00 & 60 & 467 & (30) \\
\hline 14 & 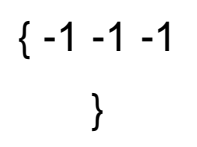 & 0 & -1 & 4 & 5.13 & 0 & 652 & (10) \\
\hline 15 & $\begin{array}{c}\{-1-1-1 \\
\}\end{array}$ & 0.5 & 0.5 & 4 & 5.56 & 45 & 618 & (13) \\
\hline 16 & $\begin{array}{c}\{-1-1-1 \\
\}\end{array}$ & -1 & 0 & 4 & 4.25 & 30 & 590 & (38) \\
\hline 17 & $\begin{array}{c}\{-1-1-1 \\
\}\end{array}$ & -1 & 0 & 4 & 4.25 & 30 & 587 & (19) \\
\hline
\end{tabular}

Coded variables value $1=$ upper limit, value $-1=$ lower limit $\quad$ A (pH); B (time)

This article is protected by copyright. All rights reserved. 
Table 3 Analysis of variance (ANOVA) of independent variables for the optimisation of protein solubilisation from bovine lung (DM1)

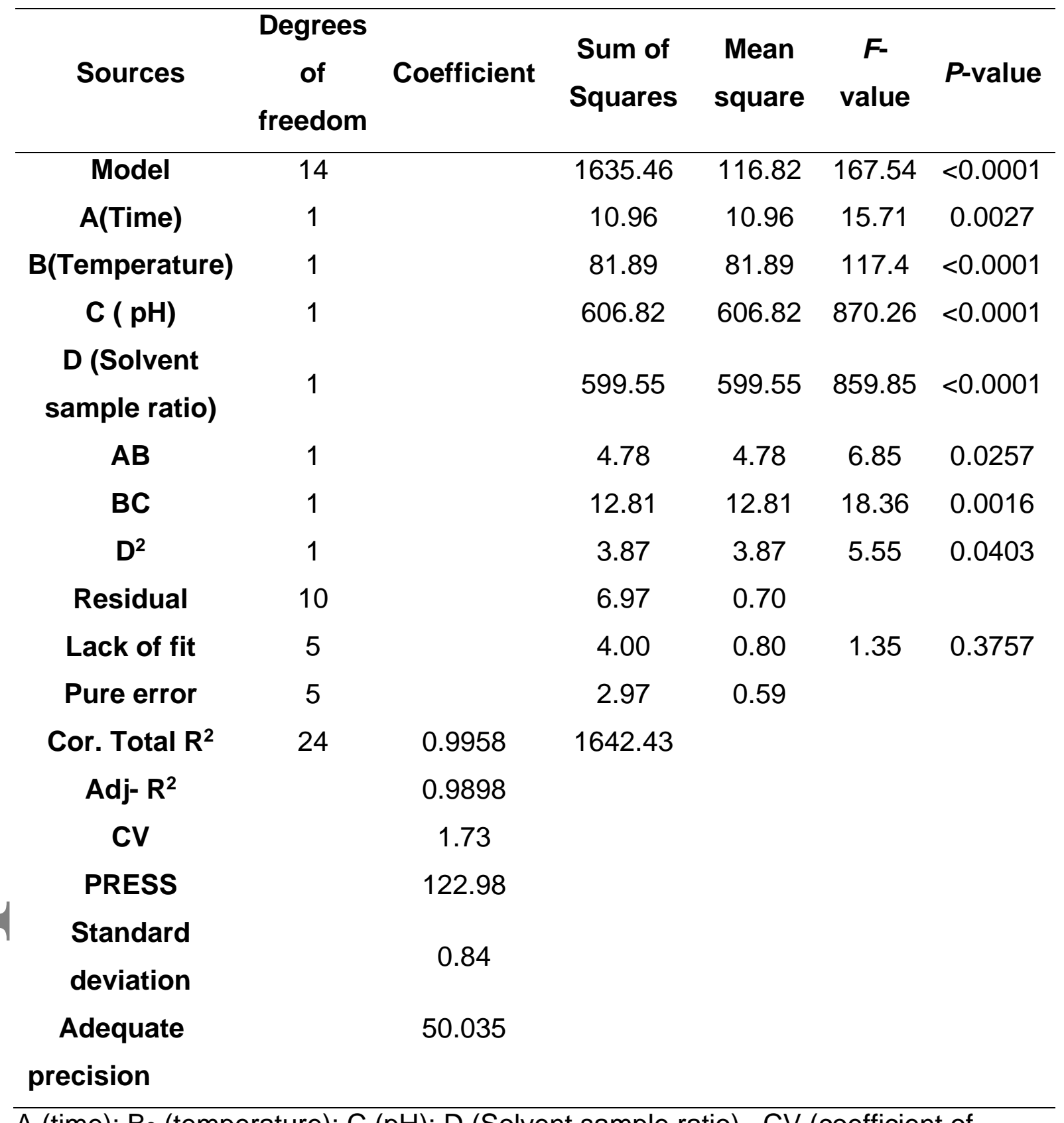

A (time); $B_{2}$ (temperature); C $(\mathrm{pH}) ; \mathrm{D}$ (Solvent sample ratio) CV (coefficient of variation); PRESS (predicted residual error sum of squares) 
Table 4 Analysis of variance (ANOVA) of independent variables for the optimisation of protein precipitation from S1 (DM2)

\begin{tabular}{|c|c|c|c|c|c|c|}
\hline Sources & $\begin{array}{l}\text { Degrees of } \\
\text { freedom }\end{array}$ & Coefficient & $\begin{array}{l}\text { Sum of } \\
\text { Squares }\end{array}$ & $\begin{array}{l}\text { Mean } \\
\text { square }\end{array}$ & $\begin{array}{c}F- \\
\text { value }\end{array}$ & $P$-value \\
\hline Block & 3 & & 488.33 & 162.78 & & \\
\hline Model & 5 & & 287.32 & 57.46 & 22.47 & 0.0002 \\
\hline$A(p H)$ & 1 & & 58.18 & 58.18 & 22.75 & 0.0014 \\
\hline B(Time) & 1 & & 0.34 & 0.34 & 0.13 & 0.7264 \\
\hline$A B$ & 1 & & 0.14 & 0.14 & 0.055 & 0.8209 \\
\hline$A^{2}$ & 1 & & 212.85 & 212.85 & 83.22 & $<0.0001$ \\
\hline$B^{2}$ & 1 & & 12.61 & 12.61 & 4.93 & 0.0571 \\
\hline Residual & 8 & & 20.46 & 2.56 & & \\
\hline Lack of fit & 4 & & 46.57 & 4.00 & 3.61 & 0.1210 \\
\hline Pure error & 4 & & 42.69 & 1.11 & & \\
\hline $\begin{array}{c}\text { Cor. Total } \\
\mathbf{R}^{2}\end{array}$ & 16 & 0.9335 & 979.76 & & & \\
\hline Adj- $R^{2}$ & & 0.8920 & & & & \\
\hline CV & & 2.93 & & & & \\
\hline PRESS & & 174.80 & & & & \\
\hline $\begin{array}{l}\text { Standard } \\
\text { deviation }\end{array}$ & & 1.60 & & & & \\
\hline $\begin{array}{l}\text { Adequate } \\
\text { precision }\end{array}$ & & 21.664 & & & & \\
\hline
\end{tabular}

A (time); B (pH); CV (coefficient of variation); PRESS (predicted residual error sum of squares) 
Table 5 Model validation for soluble protein yield from lung

\begin{tabular}{|c|c|c|c|c|c|c|c|c|}
\hline \multirow[t]{2}{*}{ ID } & \multirow[t]{2}{*}{$\begin{array}{l}\text { Time } \\
\text { (Min } \\
\text { s) }\end{array}$} & \multirow[t]{2}{*}{$\begin{array}{l}\text { Temperatu } \\
\text { re }\left({ }^{\circ} \mathrm{C}\right)\end{array}$} & \multirow[t]{2}{*}{$\mathrm{pH}$} & \multirow[t]{2}{*}{$\begin{array}{l}\text { Solve } \\
\text { nt } \\
\text { Sampl } \\
\text { e } \\
\text { Ratio }\end{array}$} & \multirow[t]{2}{*}{$\begin{array}{l}\text { Desirabili } \\
\text { ty }\end{array}$} & \multirow{2}{*}{$\begin{array}{l}\text { Predicte } \\
\text { d } \\
\text { protein } \\
\text { yield } \\
\qquad \mathbf{g ~ k g}^{-1}\end{array}$} & \multicolumn{2}{|c|}{$\begin{array}{l}\text { Actual protein } \\
\text { yield } \mathrm{g} \mathrm{kg}^{-1} \\
\text { Mean (St. dev.) }\end{array}$} \\
\hline & & & & & & & $\begin{array}{c}\text { Bovin } \\
\text { e }\end{array}$ & $\begin{array}{c}\text { Porcin } \\
\text { e }\end{array}$ \\
\hline $\begin{array}{c}\text { MV } \\
-1\end{array}$ & 140 & 19 & $\begin{array}{c}10 . \\
8\end{array}$ & 13.02 & 1.000 & 655 & $\begin{array}{c}661 \\
(24)^{\mathrm{a}}\end{array}$ & $\begin{array}{c}686 \\
(13)^{\mathrm{a}}\end{array}$ \\
\hline $\begin{array}{l}\text { MV } \\
-2\end{array}$ & 120 & 20 & 8.6 & 10.00 & 0.714 & 556 & $\begin{array}{c}598 \\
(33)^{\mathrm{a}}\end{array}$ & $\begin{array}{l}591 \\
(58)^{\mathrm{a}}\end{array}$ \\
\hline $\begin{array}{l}\text { MV } \\
-3\end{array}$ & 60 & 20 & 8.4 & 10.00 & 0.662 & 539 & $\begin{array}{l}542 \\
(19)\end{array}$ & \\
\hline $\begin{array}{l}\text { MV } \\
-4\end{array}$ & 167 & 20 & 9.5 & 14.98 & 0.908 & 619 & $\begin{array}{l}655 \\
(10)\end{array}$ & \\
\hline $\begin{array}{l}\text { MV } \\
-5\end{array}$ & 120 & 20 & $\begin{array}{c}11 . \\
0\end{array}$ & 7.50 & 0.870 & 607 & $\begin{array}{l}611 \\
(41)\end{array}$ & \\
\hline
\end{tabular}

a Different letters within a row indicate significant differences $(P<0.05)$ according to independent samples $t$ test 
Table 6 Validation of optimum conditions for solubilisation and precipitation of protein used in sequence with $2 \mathrm{~L}$ extraction volume

\begin{tabular}{|c|c|c|c|c|c|c|c|c|}
\hline & $\begin{array}{l}\text { Time } \\
\text { (min } \\
\text { ) }\end{array}$ & $\begin{array}{l}\text { Tem } \\
\mathbf{p}^{\circ} \mathbf{C}\end{array}$ & pH & $\begin{array}{l}\text { Solven } \\
\text { t } \\
\text { sample } \\
\text { ratio }\end{array}$ & $\begin{array}{l}\text { Solubilise } \\
\text { d protein } \\
\text { Yield } \\
\text { Mean } \mathbf{g} \\
\text { kg }^{-1}( \pm)\end{array}$ & $\begin{array}{l}\text { Time } \\
\text { (min } \\
\text { ) }\end{array}$ & pH & $\begin{array}{l}\text { Precipitate } \\
\text { d protein } \\
\text { Yield Mean } \\
\text { g kg }^{-1}( \pm)\end{array}$ \\
\hline $\begin{array}{c}\text { Bovine } \\
\text { Lung }\end{array}$ & 140 & 19 & $\begin{array}{c}10 . \\
8\end{array}$ & 13.02 & $660(40)^{a}$ & 60 & $\begin{array}{c}5.0 \\
3\end{array}$ & $625(25)^{b}$ \\
\hline $\begin{array}{l}\text { Porcin } \\
\text { e lung }\end{array}$ & 140 & 19 & $\begin{array}{c}10 . \\
8\end{array}$ & 13.02 & $728(44)^{a}$ & 60 & $\begin{array}{c}5.0 \\
3\end{array}$ & $581(67)^{b}$ \\
\hline
\end{tabular}

This article is protected by copyright. All rights reserved. 
Table 7 Composition of bovine and porcine lung and recovered protein ( $\left.\mathrm{g} \mathrm{kg}^{-1}\right)$

\begin{tabular}{|c|c|c|c|c|}
\hline \multirow{2}{*}{$\begin{array}{l}\text { Sample type } \\
\text { Species }\end{array}$} & \multicolumn{2}{|c|}{ Minced lung } & \multicolumn{2}{|c|}{ Recovered protein } \\
\hline & Bovine & Porcine & Bovine & Porcine \\
\hline Total Protein & $187(6)^{a}$ & $173(7)^{b}$ & $116(7)^{\mathrm{c}}$ & $109(13)$ \\
\hline Fat & $17(5)^{a}$ & $28(8)^{b}$ & $10(3)^{c}$ & $16 \quad(1)$ \\
\hline Moisture & $779(9)^{a}$ & $784(7)^{b}$ & $863(6)^{c}$ & $843(10)^{d}$ \\
\hline Ash & $11(1)^{a}$ & $12(2)^{a}$ & $5(2)^{c}$ & $(1)^{\mathrm{c}}$ \\
\hline Collagen & $(3)^{a}$ & $344^{(5)^{b}}$ & ND & ND \\
\hline
\end{tabular}

a Different letters within a row for the same sample type indicate significant differences $(P<0.05)$ according to independent samples $t$ test.

Values $\left(\mathbf{g ~ k g}^{-1}\right)$ are presented as mean (Standard deviation). ND None detected. 
Figure 1
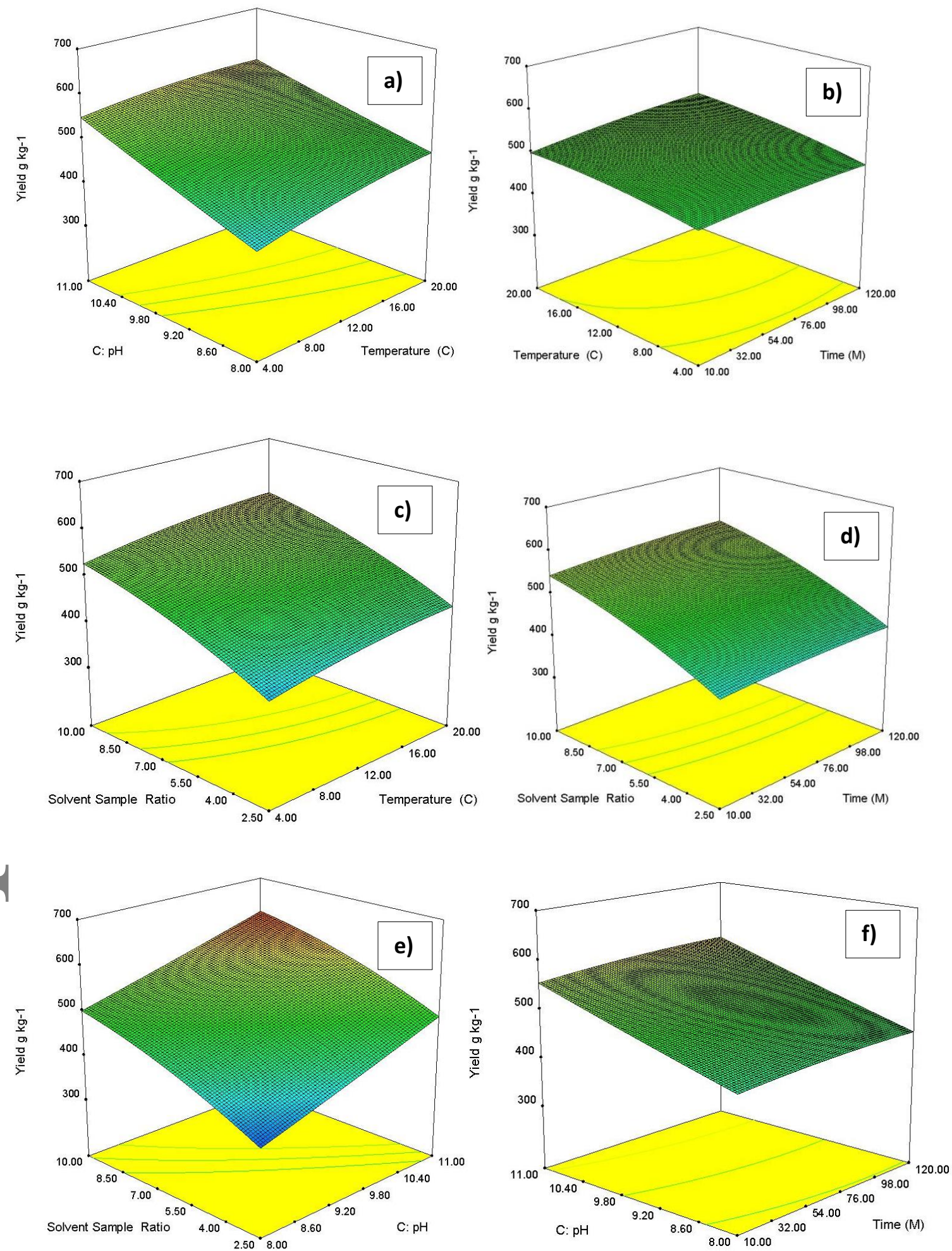

Figure 1:3D contour plots for yield of soluble protein from bovine lung ; (a) temperature and $\mathrm{pH}$; (b) time and temperature; (c) temperature and solvent sample ratio; (d) time and solvent sample ratio: (e) solvent sample ratio and $\mathrm{pH}$; (f) time and $\mathrm{pH}$. Remaining variables were fixed at coded zero level.

This article is protected by copyright. All rights reserved. 
Figure 2

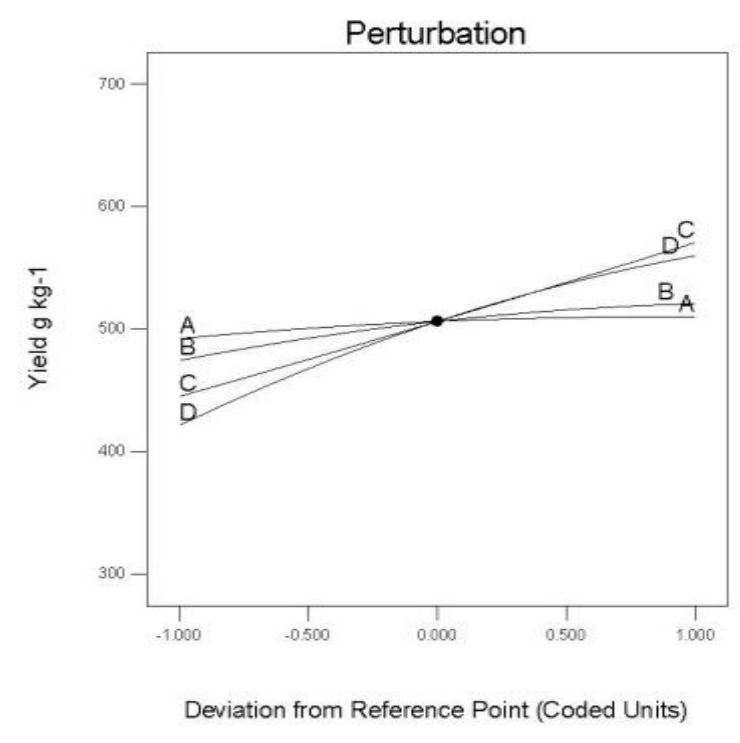

Figure 2: Perturbation plot of soluble protein yield. Actual factors A (Time): 65.0 minutes; $B$ (Temperature in $\left.{ }^{\circ} \mathrm{C}\right)$ : $12.00 ; \mathrm{C}(\mathrm{pH})$ : 9.50; $\mathrm{D}$ (Sample solvent sample ratio): 6.25 to 1 .

This article is protected by copyright. All rights reserved. 
Figure 3

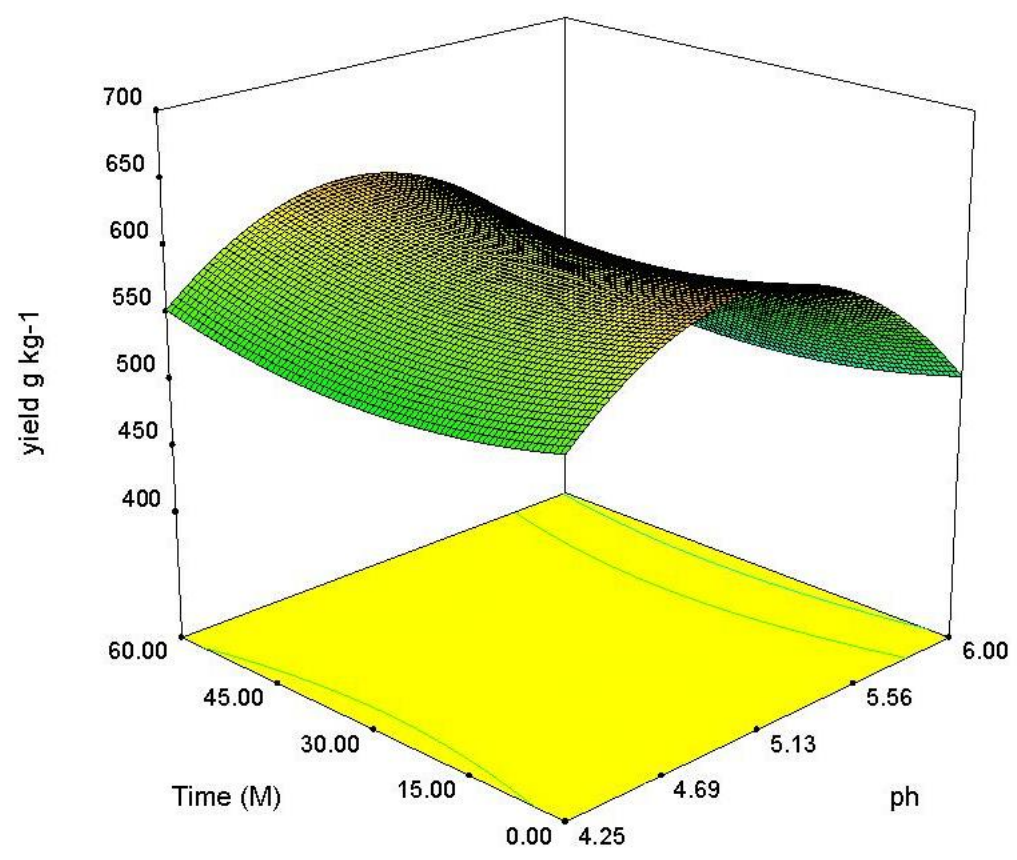

Figure 3: Yield of soluble protein recovered by precipitation as a function of time and $\mathrm{pH}$.

This article is protected by copyright. All rights reserved. 
Figure 4

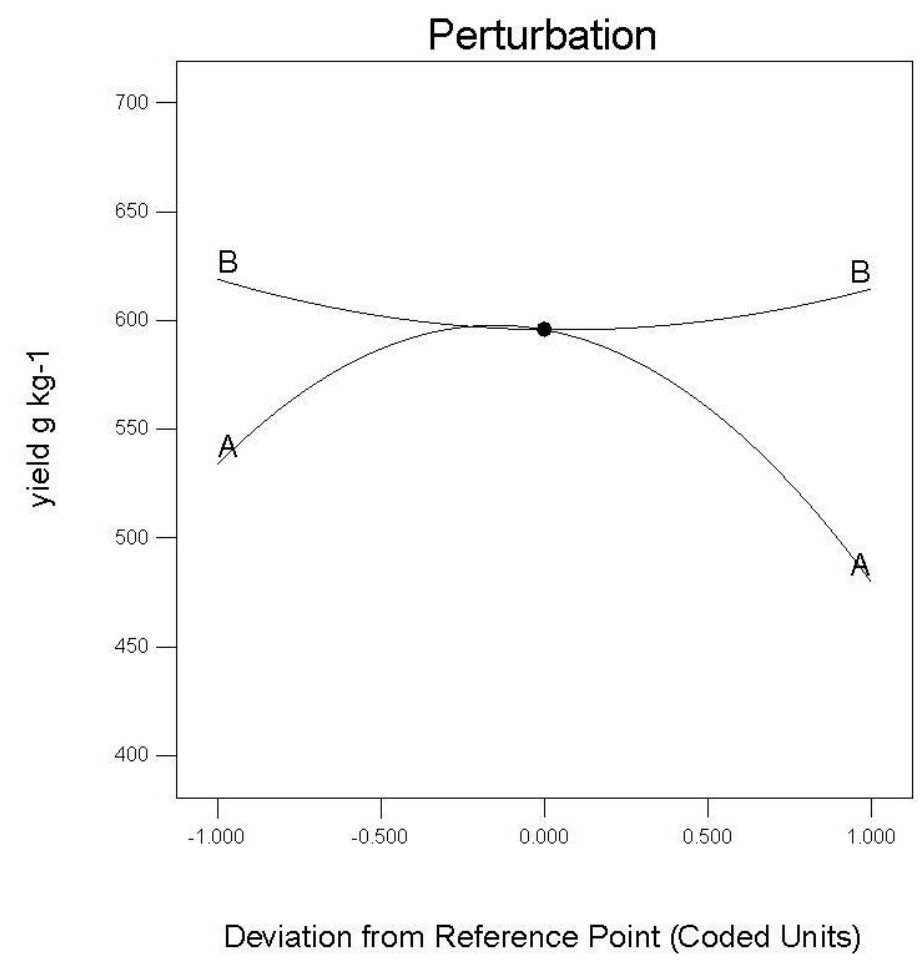

Figure 4: Perturbation plot for recovered protein yield. Actual factors $A(p H)$ : 5.13; B (time): 30 minutes.

This article is protected by copyright. All rights reserved. 